\title{
Virus-Poly(3,4-ethylenedioxythiophene) Biocomposite Films
}

\author{
Keith C. Donavan, Jessica A. Arter, Gregory A. Weiss,* and Reginald M. Penner* \\ Department of Chemistry, University of California, Irvine, California 92697-2025, United States
}

ABSTRACT: Virus-poly(3,4-ethylenedioxythiophene) (virusPEDOT) biocomposite films are prepared by electropolymerizing 3,4-ethylenedioxythiophene (EDOT) in aqueous electrolytes containing $12 \mathrm{mM} \mathrm{LiClO}_{4}$ and the bacteriophage M13. The concentration of virus in these solutions, [virus] $]_{\text {soln }}$ is varied from 3 to $15 \mathrm{nM}$. A quartz crystal microbalance is used to directly measure the total mass of the biocomposite film during its electrodeposition. In combination with a measurement of the electrodeposition charge, the mass of the virus incorporated into the film is calculated. These data show that the concentration of the M13 within the electropolymerized film, $[\text { virus }]_{\text {film }}$, increases linearly with [virus $]_{\text {soln }}$. The incorporation of virus particles into the PEDOT film from solution is efficient, resulting in a

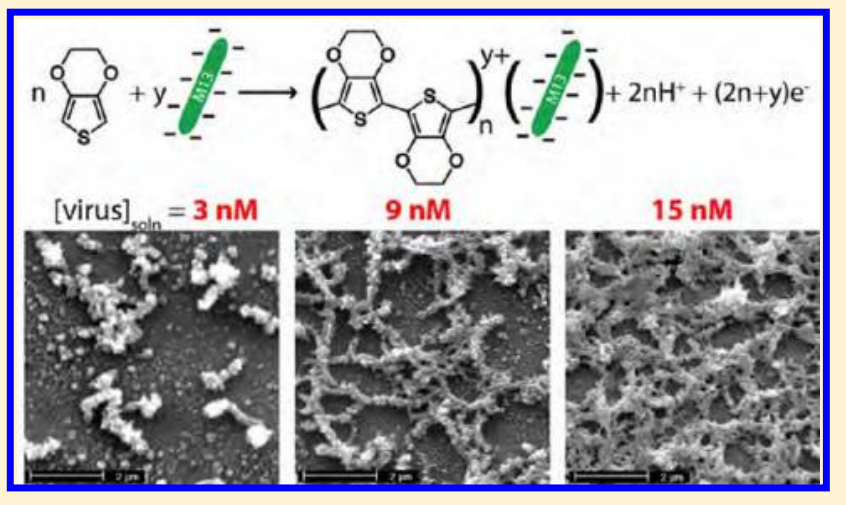
concentration ratio of [virus $]_{\text {film }}:[\text { virus }]_{\text {soln }} \approx 450$. Virus incorporation into the PEDOT causes roughening of the film topography that is observed using scanning electron microscopy and atomic force microscopy (AFM). The electrical conductivity of the virus-PEDOT film, measured perpendicular to the plane of the film using conductive tip AFM, decreases linearly with virus loading, from $270 \mu \mathrm{S} / \mathrm{cm}$ for pure PEDOT films to $50 \mu \mathrm{S} / \mathrm{cm}$ for films containing $100 \mu \mathrm{M}$ virus. The presence on the virus surface of displayed affinity peptides did not significantly influence the efficiency of incorporation into virus-PEDOT biocomposite films.

\section{INTRODUCTION}

Biocomposite films consisting of a protein component and an electronically conductive organic polymer such as polypyrrole, polyaniline, or poly(3,4-ethylenedioxythiophene)(PEDOT) provide an expedient route to the preparation of neural electrodes, ${ }^{1-3}$ biocompatible surfaces, ${ }^{4-6}$ biosensors, ${ }^{7-13}$ and gas sensors. ${ }^{14}$ Such biocomposite films can often be synthesized in a single step involving the electropolymerization of monomer from aqueous electrolytes in the presence of the protein. ${ }^{15}$ PEDOT is an attractive polymer for the preparation of such biocomposites due to its excellent electrical stability, ${ }^{3}$ high electrical conductivity, ${ }^{16}$ and biocompatibility. ${ }^{17-19}$ Recent work has demonstrated that PEDOT is capable of incorporating large biomolecules including fibrinogen $(\mathrm{MW}=330 \mathrm{kDa})^{16}$ and collagen $(\mathrm{MW}=300 \mathrm{kDa})^{20}$ (Table 1$)$.

Biocomposites of conductive polymers and virus particles have been prepared previously: Biocomposite fibers composed of virus particles, including $\mathrm{M} 13^{21,22}$ and tobacco mosaic virus (TMV), ${ }^{14,23,24}$ and conductive polymers have been prepared by chemical polymerization. The quantity of virus particles incorporated into these polymer fibers, however, was not measured in these studies.

Previously, we have shown that composites of PEDOT and filamentous bacteriophage M13 can be prepared by electrodeposition. $^{25-27} \mathrm{M} 13$ is a filamentous virus that is $6 \mathrm{~nm}$ in width, is $\sim 1.0 \mu \mathrm{m}$ in length, and has a $\mathrm{MW}=16.4 \mathrm{MDa}^{28}$ Films and nanowires composed of this virus-PEDOT biocomposite have been used as the basis for biosensors. ${ }^{25-27}$ Upon exposure to solutions containing a target molecule that binds to the virus particles, films of the virus-PEDOT biocomposite show an increased electrical impedance, ${ }^{26}$ while nanowires show an increased dc resistance. ${ }^{25,27}$ The mechanism of this electrical transduction process has not been determined and remains under investigation. To elucidate the mechanism of transduction and to optimize the performance of these biosensors, the influence of the concentration of the M13 particles within the PEDOT matrix on the biosensing response must be understood. The purpose of this Article is to establish the means to measure and control the M13 content of electrodeposited virus-PEDOT films, and to observe the influence of virus incorporation on the morphology and electrical conductivity of these biocomposites.

This Article has four specific objectives. The first is to establish a quantitative relationship between the virus concentration in the EDOT polymerization solution, $[\text { virus }]_{\text {soln }}$, and the virus concentration in the biocomposite film, $[\text { virus }]_{\text {film }}$ prepared by electrodeposition. Quartz crystal microbalance (QCM) gravimetry ${ }^{29-33}$ and coulometry permit this correlation to be established. Second is to determine the influence of virus particles in the polymerization solution on the rate of the electropolymerization process. Electrochemical measurements provide this information. Third is to determine the influence of virus particles on the film thickness and the film surface topography. Scanning electron microscopy and atomic force

Received: June 18, 2012

Revised: July 31, 2012

Published: August 2, 2012 
Table 1. Biocomposites of Polymers with Nonenzymatic Biomolecules

\begin{tabular}{|c|c|c|c|c|c|}
\hline biomolecule (MW) & polymer & incorporation method & $\Gamma^{a}\left(\mu \mathrm{g} / \mathrm{cm}^{2}\right)$ & measurement technique & reference \\
\hline concanavalin A $(26.5 \mathrm{kDa})$ & poly-(acrylonitrile) & adsorption & 0.79 & QCM & Che et ll. $^{29}$ \\
\hline cytochrome $\mathrm{C}(12.4 \mathrm{kDa})$ & poly-(3-methylthiophene) & bioaffinity interaction & 0.192 & cytochrome $\mathrm{C}$ redox & Eguilaz et al. $^{45}$ \\
\hline DNA $(6.01 \mathrm{kDa})$ & PEDOT & adsorption & 0.027 & nile blue redox & Chen et al. ${ }^{46}$ \\
\hline DNA $(5.94 \mathrm{kDa})$ & PEDOT & covalent attachment & 0.025 & toluidine blue abs & Luo et al. $^{47}$ \\
\hline hyaluronic acid (400 kDa) & polypyrrole & covalent attachment & 3.0 & toluidine blue abs & Cen et al. ${ }^{1}$ \\
\hline heparin $(15 \mathrm{kDa})$ & PEDOT & electrochemical codeposition & 9.0 & toluidine blue abs & Asplund et al. ${ }^{16}$ \\
\hline hyaluronic acid (400 kDa) & PEDOT & electrochemical codeposition & 12.0 & toluidine blue abs & Asplund et al. ${ }^{16}$ \\
\hline $\mathrm{TMV}^{b}(40 \mathrm{MDa})$ & polyaniline & chemical codeposition & n.a. & n.a. & Niu et al. ${ }^{24}$ \\
\hline M13 (16.4 MDa) & polyaniline & chemical codeposition & n.a. & n.a. & Niu et al. ${ }^{21}$ \\
\hline M13 (16.4 MDa) & PEDOT & electrochemical codeposition & $2.4-7.4^{c}$ & QCM & this work \\
\hline
\end{tabular}

${ }^{a} \Gamma$ is the mass-based coverage of the surface by the biomolecule of interest. ${ }^{b}$ Tobacco Mosaic Virus. ${ }^{c}$ The range of incorporated M13 mass measured for $[\text { virus }]_{\text {soln }}=3$ and $15 \mathrm{nM}$.

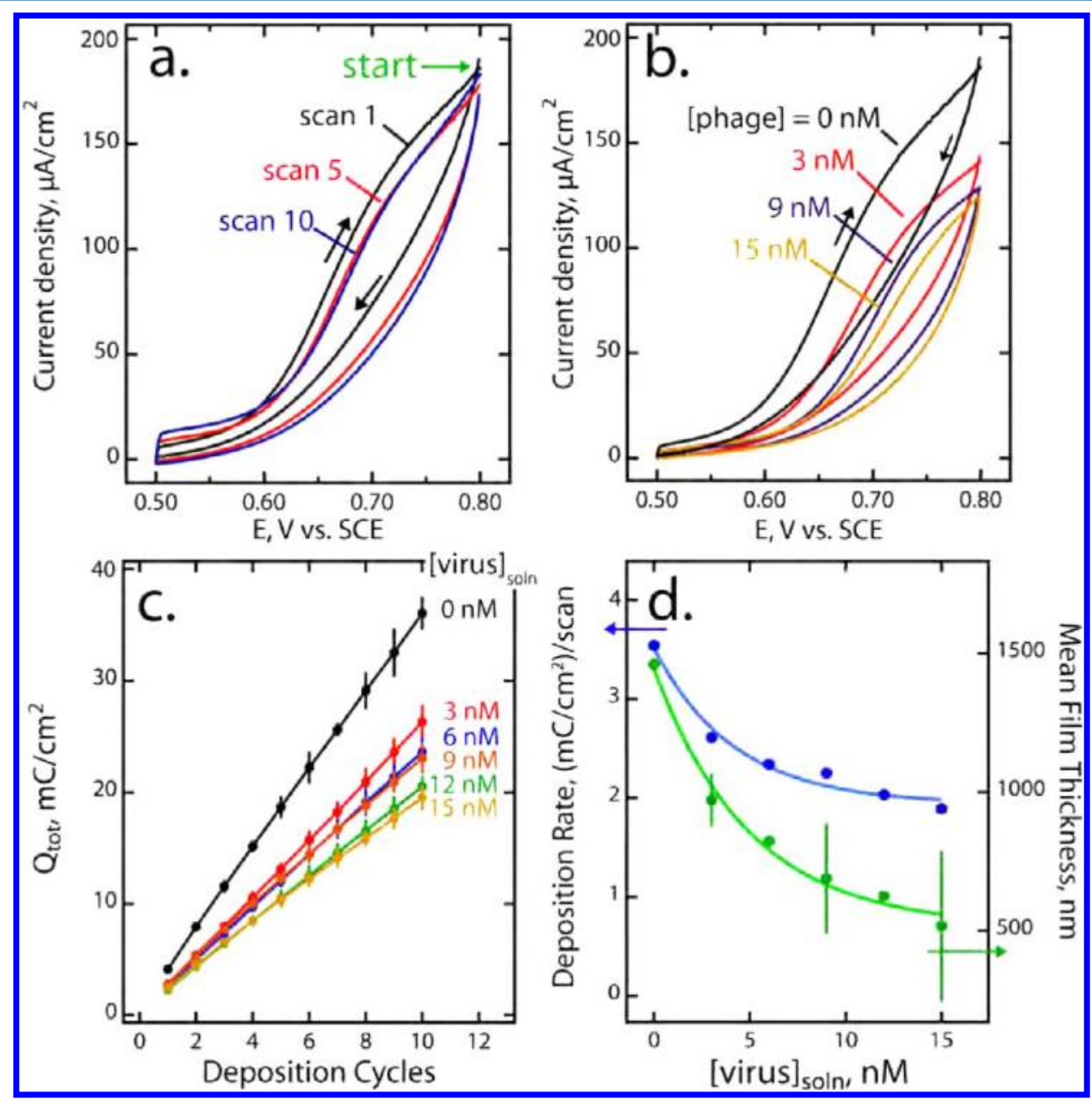

Figure 1. Electrodeposition of a virus-PEDOT composite film. (a) Anodic polymerization at $20 \mathrm{mV} / \mathrm{s}$ of EDOT only at a gold electrode. The solution was aqueous $12.5 \mathrm{mM} \mathrm{LiClO}, 2.5 \mathrm{mM}$ EDOT. (b) Anodic polymerization at $20 \mathrm{mV} / \mathrm{s}$ of EDOT in the presence of M13 virus at the indicated concentrations. (c) Deposition charge versus cycle number for the growth of PEDOT and virus-PEDOT films as a function of the virus concentration as indicated. (d) Deposition rate versus [virus $]_{\text {soln }}$, obtained from the slope of the plots shown in (c), and film thickness, measured by $\mathrm{AFM}$, versus $[\text { virus }]_{\text {soln }}$. Error bars represent the rms roughness of these film surfaces.

microscopy are used to probe the topography of the film surface. Fourth is to measure the influence of virus incorporation on the electrical conductivity of the biocomposite film. Conductive tip AFM is used for this purpose.

\section{EXPERIMENTAL SECTION}

Materials. All chemicals and reagents were purchased from SigmaAldrich and used as received, unless otherwise noted. Milli-Q UV water $(\rho>18 \mathrm{M} \Omega \mathrm{cm})$ was used for the preparation of all solutions and for the rinsing of all samples.

Synthesis of Virus-PEDOT Films. Circular gold electrodes $(3 \mathrm{~mm}$ diameter, $\mathrm{CH}$ Instruments) were cleaned by mechanical polishing with progressively smaller particle size diamond polishing compound (1 $\mu \mathrm{m}, 0.25 \mu \mathrm{m}$, and $0.1 \mu \mathrm{m}$, Ted Pella) on a polishing microcloth (Buehler) and sonicated in water for $10 \mathrm{~min}$ each. The electrodes were then placed in fresh piranha solution $\left(3: 1 \mathrm{H}_{2} \mathrm{SO}_{4}: \mathrm{H}_{2} \mathrm{O}_{2}\right)$ for $10 \mathrm{~min}$. Electrodes were then rinsed thoroughly with water and dried under a 


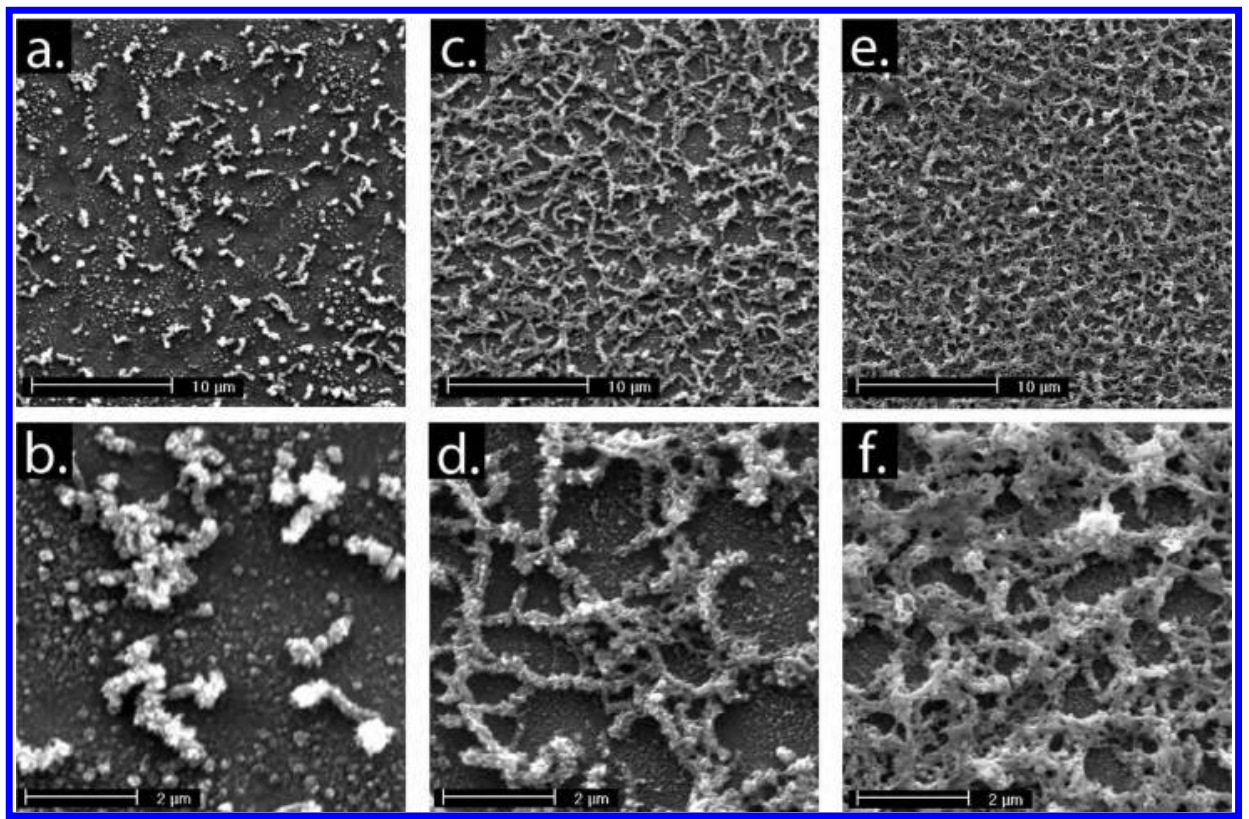

Figure 2. Topography of virus-PEDOT films imaged by scanning electron microscopy at two magnifications. All films were prepared using 10 deposition cycles $(20 \mathrm{mV} / \mathrm{s})$ from a solution of aqueous $12.5 \mathrm{mM} \mathrm{LiClO}_{4}, 2.5 \mathrm{mM}$ EDOT, and virus particles at three concentrations: (a,b) $[\text { virus }]_{\mathrm{soln}}=3 \mathrm{nM},(\mathrm{c}, \mathrm{d})[\text { virus }]_{\mathrm{soln}}=9 \mathrm{nM}$, and $(\mathrm{e}, \mathrm{f})[\text { virus }]_{\text {soln }}=15 \mathrm{nM}$.

stream of dried nitrogen gas. To ensure reproducible positioning of the platinum wire counter electrode, it was wrapped around the tip of the cleaned gold working electrode and held in place using tape, as previously described. ${ }^{34,35}$ A saturated mercurous sulfate (MSE) reference electrode was used. These electrodes were placed in the virus-PEDOT plating solution $\left(12.5 \mathrm{mM} \mathrm{LiClO}_{4}, 2.5 \mathrm{mM}\right.$ EDOT, and 3-15 $\mathrm{nM} \mathrm{M13} \mathrm{bacteriophage)} \mathrm{and} \mathrm{equilibrated} \mathrm{for} 1 \mathrm{~min}$. Electropolymerization occurred by scanning from 0.80 to $0.20 \mathrm{~V}$ vs MSE for 10 cycles using a PARSTAT 2273 controlled by POWERCV software (Princeton Applied Research) at a scan rate of $20 \mathrm{mV} / \mathrm{s}$. The total electrodeposition charge, $Q_{\text {tot }}$ was calculated by integrating the current for these scans. Freshly synthesized virus-PEDOT films were then rinsed with water and immediately analyzed.

Cyclic Voltammetry Analysis. Cyclic voltammetry measurements were performed on virus-PEDOT films with varying concentrations of virus in $12.5 \mathrm{mM} \mathrm{LiClO}_{4}$ with a $50 \mathrm{mV} / \mathrm{s}$ scan rate.

Conducting AFM and SEM Analysis. Conducting tip atomic force microscopy (c-AFM) imaging was performed in a laboratory air ambient using an Asylum MFP-3D-SA atomic force microscope (Asylum Research) and Asylum ASYELEC-01 tips in the ORCA module. Briefly, a sample bias of up to $2.0 \mathrm{~V}$ was applied to the gold surface on which the electropolymerized virus-PEDOT films were supported, while the AFM tip was maintained at virtual ground. Topographs were obtained over a $20 \mu \mathrm{m}$ range at $512 \times 512$ pixels and flattened line by line. A current histogram was generated with current values measured at each pixel along the image. Image processing was performed via attached software package provided with the AFM. Scanning electron microscopy was performed using a Philips XL30 FEG SEM at an operating voltage of $10.0 \mathrm{keV}$. All samples were coated with a thin layer of $\mathrm{Au}-\mathrm{Pd}$ by sputter-coating prior to SEM examination.

QCM Analysis. Gold-coated AT-cut quartz crystals (5 MHz, Stanford Research Systems) were used as working electrodes for the electrodeposition of virus-PEDOT composite films via a modified version of the method previously described. ${ }^{25-27} \mathrm{~A}$ virus-PEDOT plating solution $(10 \mathrm{~mL})$ was placed in a Teflon QCM cell together with a planar platinum counter electrode and a MSE reference electrode. This solution was equilibrated for $1 \mathrm{~min}$ prior to electrodeposition. The frequency of the crystal was monitored using a $5 \mathrm{MHz}$ frequency oscillator (Stanford Research Systems, model QCM 25) and frequency digital controller (Stanford Research Systems, model QCM 200) interfaced to a LabView program. After deposition, the QCM crystals were rised with water and dried in a 175 ${ }^{\circ} \mathrm{C}$ vacuum oven for $6 \mathrm{~h}$. The mass of these films was then measured again by QCM to obtain the dry weight of the film. The mass of the incorporated virus was calculated using the following equation, which is based upon calibration of the QCM crystal using silver electrodeposition:

$$
\begin{aligned}
& \Delta m_{\text {virus }}=\frac{1}{K}\left[\Delta f_{\text {virus-PEDOT }}-\Delta f_{\text {PEDOT }}\right] \\
& \Delta m_{\text {virus }}=\frac{1}{K}\left[\Delta f_{\text {virus-PEDOT }}-\left(m Q_{\text {tot }}+b\right)\right]
\end{aligned}
$$

where $\Delta f_{\text {virus-PEDOT }}$ is the total frequency change resulting from virusPEDOT film electrodeposition, $\Delta f_{\text {PEDOT }}$ is the frequency change attributable to the PEDOT component only, and $Q_{\text {tot }}$ is the total electrodeposition charge. $K, m$, and $b$ are constants determined from calibration. For in situ QCM measurements, $K=55.9 \mathrm{~Hz} \mathrm{~cm}^{2} \mu \mathrm{g}^{-1}, m$ $=1.3 \times 10^{7} \mathrm{~Hz} \mathrm{~cm}^{2} \mathrm{C}^{1-1}$, and $b=56 \mathrm{~Hz}$; whereas for ex situ measurements of dried films, $K=49.0 \mathrm{~Hz} \mathrm{~cm}^{2} \mu \mathrm{g}^{-1}, m=4.4 \times 10^{6} \mathrm{~Hz}$ $\mathrm{cm}^{2} \mathrm{C}^{-1}$, and $b=120 \mathrm{~Hz}$.

\section{RESULTS AND DISCUSSION}

Virus-PEDOT biocomposite films were prepared by electrodeposition from solutions containing both virus particles and the monomer EDOT using cyclic voltammetry. ${ }^{36}$ For aqueous solutions of $12.5 \mathrm{mM} \mathrm{LiClO}_{4}$ and $2.5 \mathrm{mM}$ EDOT containing no virus particles, the onset for EDOT polymerization takes place at $+0.58 \mathrm{~V}$ vs MSE, and little change in the amplitude of the peak oxidation current occurs over 10 successive scans (Figure 1a). As the virus concentration in the plating solution, [virus $]_{\text {soln }}$, is increased, the peak oxidation current is progressively reduced as compared to the virus-free control (Figure $1 \mathrm{~b}$ ). Because successive deposition scans produce the same deposition charge, $Q_{\text {tot }}$ (Figure 1a), plots of $Q_{\text {tot }}$ versus deposition cycles are linear (Figure 1c) with slopes that vary inversely with the virus concentration (Figure 1d). The film thickness obtained after 10 deposition cycles also decreased with increasing [virus] soln from $1.5 \mu \mathrm{m}$ for pure PEDOT to 0.5 $\mu \mathrm{m}$ for $[\text { virus }]_{\mathrm{soln}}=15 \mathrm{nM}$ (Figure $\left.1 \mathrm{~d}\right)$. Because $Q_{\text {tot }}$ derives 

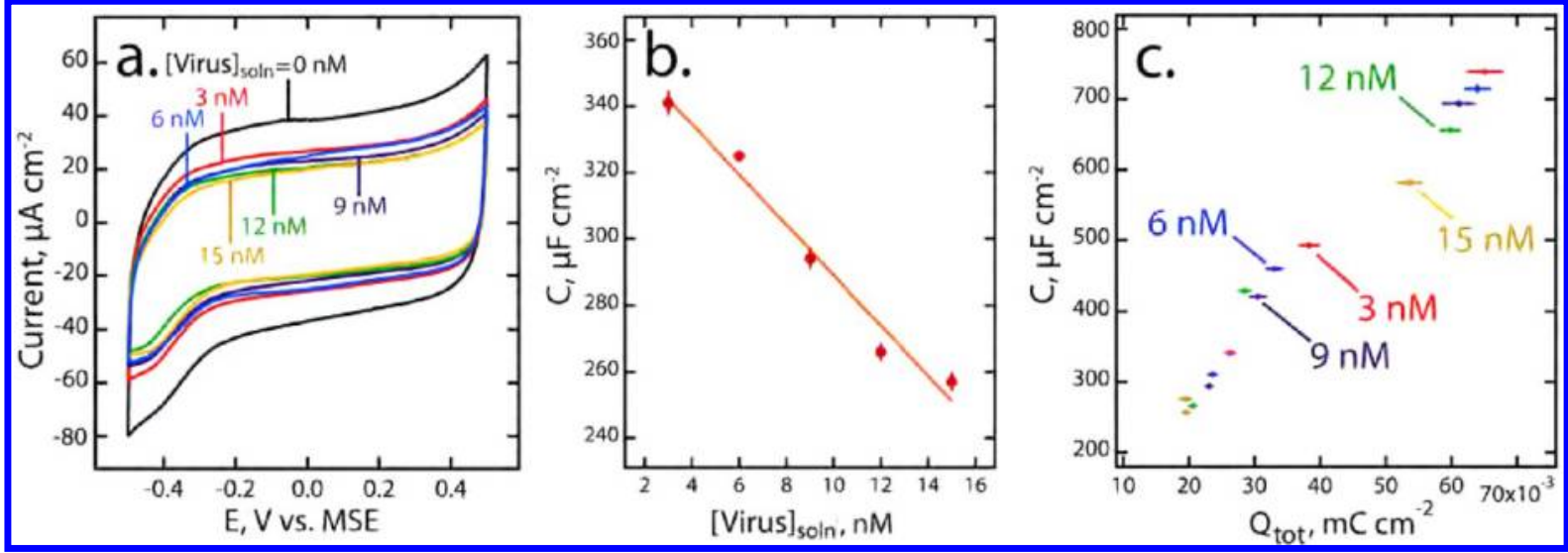

Figure 3. Voltammetry of virus-PEDOT films: (a) Steady-state cyclic voltammetry of PEDOT only (black) and virus-PEDOT films (colors, as indicated) in aqueous $12.5 \mathrm{nM} \mathrm{LiClO}_{4}$ for virus-PEDOT films prepared using 10 deposition scans. The virus concentration in the polymerization solution, [virus $]_{\text {soln }}$, is indicated. (b) Capacitance versus [virus $]_{\text {soln }}$ derived from the cyclic voltammograms shown in (a). (c) Capacitance versus deposition charge, $Q_{\text {tot }}$, for PEDOT and virus-PEDOT films showing that the total film capacitance is unaffected by the incorporation of virus from solution.

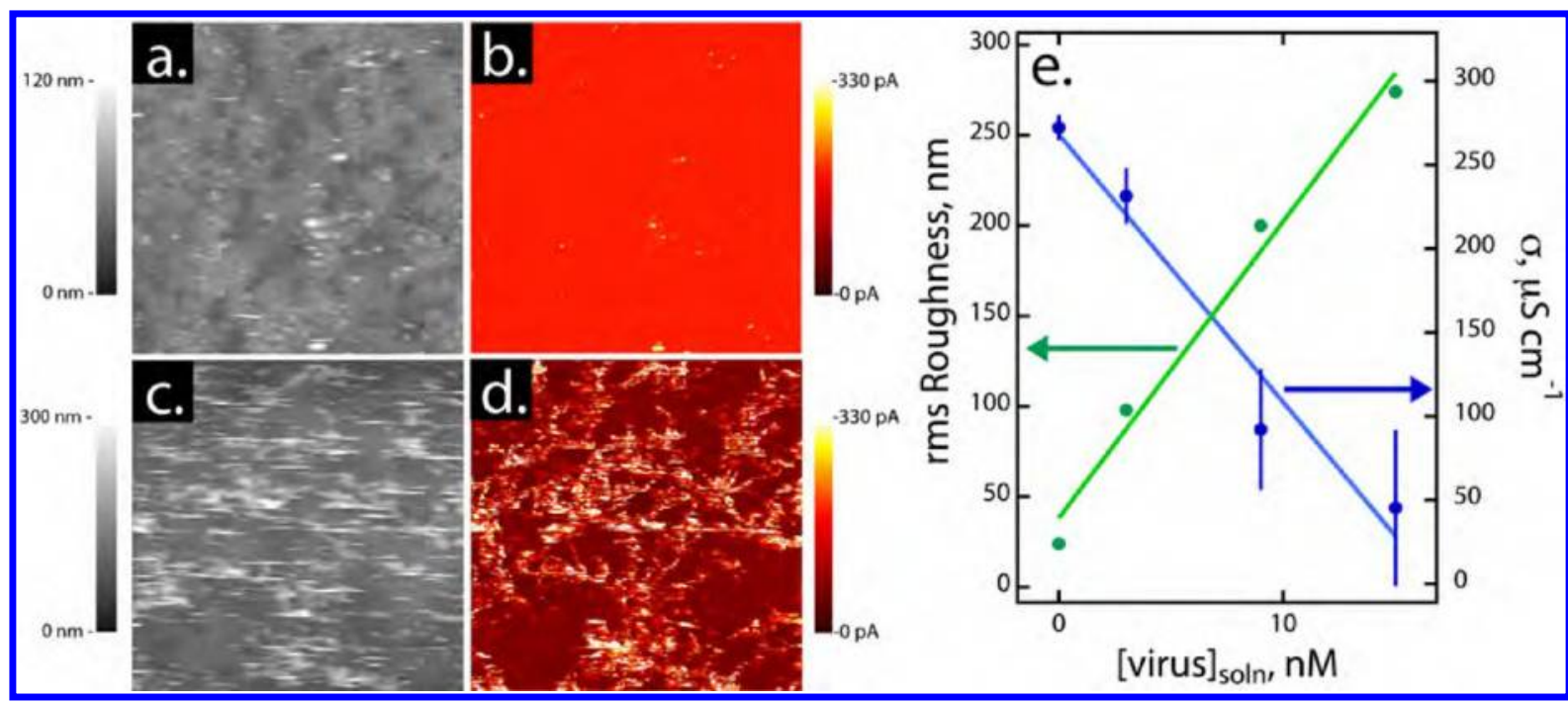

Figure 4. Concurrent topographic (a,c) and conductive tip AFM (c-AFM, b,d) images $(20 \mu \mathrm{m} \times 20 \mu \mathrm{m})$ of two films: (a) a PEDOT film showing smooth morphology ( $\mathrm{rms}$ roughness $\approx 20 \mathrm{~nm}$ ). (b) Map of the c-AFM tip-film current as a function of position acquired simultaneously with the topography image shown in (a). An imaging bias of $500 \mathrm{mV}$ was used for the acquisition of this data. (c) A virus-PEDOT film prepared from a $9 \mathrm{nM}$ loading solution (rms roughness $\approx 200 \mathrm{~nm}$ ). (d) Map of the c-AFM tip-film current as a function of position acquired simultaneously with the topography image shown in (c). An imaging bias of $2 \mathrm{~V}$ was used for the acquisition of this image, which is characterized by a highly corrugated electrical conductivity with a high conductivity at protrusions seen in (c). (e) Calculated mean film conductivity, $\sigma$, and rms roughness as a function of the virus concentration in the polymerization solution. Error bars represent $\pm 1 \mathrm{std} \operatorname{dev}$ for the spatial variability of $\sigma$.

exclusively from the polymerization of EDOT to PEDOT, the data of Figure 1c,d show that M13 interferes with the electropolymerization of EDOT.

The surface of the biocomposite film, observed by scanning electron microscopy, becomes rougher as $[\text { virus }]_{\text {soln }}$ increases. In the absence of added virus, the surface of the PEDOT film is smooth and featureless (data not shown). The protrusions seen in Figure 2a, which are $100-500 \mathrm{~nm}$ in size, are observed exclusively when virus is present in the polymerization solution. The number of these protrusions on the surface of the bicomposite film increase with $[\text { virus }]_{\text {soln }}$ (Figure $2 c-f$ ), suggesting that this topography correlates with the incorporation of virus into the PEDOT film. This conclusion is reinforced by measurements of the surface roughness using atomic force microscopy, described below. The SEM images of Figure 2 resemble those for fibrinogen ${ }^{16}$ and collagen $^{20}$ incorporated into PEDOT films, as well as the SEMs of virus incorporated into PEDOT films that we have previously published. ${ }^{26}$ The dimensions of these protrusions are $20-80$ times the diameter of individual virus particles $(\sim 6 \mathrm{~nm})$, and this suggests that these protrusions consist of bundles of filamentous virus particles, possibly encapsulated in a layer of PEDOT.

The capacitance of the virus-PEDOT film is an important attribute from the standpoint of its biosensing behavior because changes in the capacitance of the film contribute to the impedance change induced by the binding of a target analyze molecule. ${ }^{26}$ The capacitance of pure PEDOT and virusPEDOT films prepared using 10 deposition cycles was measured in $12.5 \mathrm{mM} \mathrm{LiClO}_{4}$ using cyclic voltammetry $(\mathrm{CV}$, Figure 3a). The film capacitance, $C$, was obtained from the amplitude of the current envelope, $i_{\mathcal{c}}$ according to the 


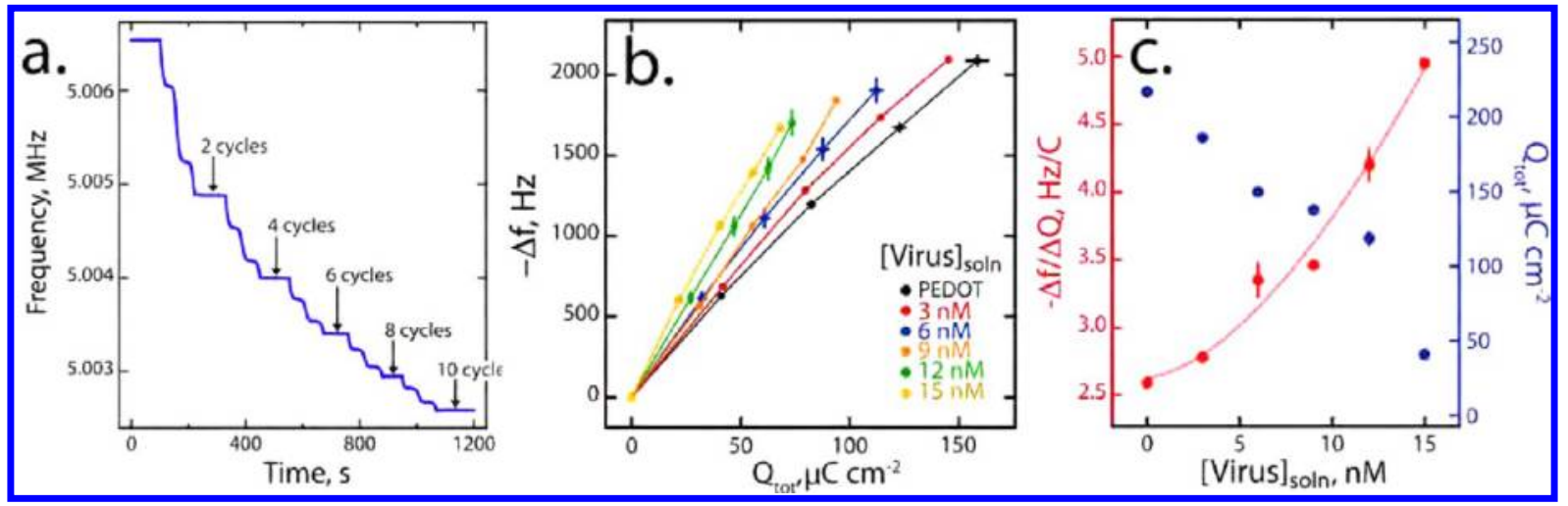

Figure 5. Quartz crystal microbalance (QCM) analyses of film growth. (a) Raw, in situ QCM frequency versus time trace obtained during the electrodeposition of a PEDOT film on a gold-coated QCM crystal. The number of electrodeposition cycles, as shown in Figure 1a,b, are indicated. The frequency-to-mass conversion factor for the QCM is $55.9 \pm 0.7 \mathrm{~Hz} \mathrm{~cm}^{2} \mu \mathrm{g}^{-1}$. (b) Frequency versus deposition charge for QCM crystal measurements. (c) The change in frequency over the change in total charge (b) (left) and total deposition charge (right) versus virus concentration indicate corresponding trends upon increasing virus concentration in the deposition solution.

equation: $i_{c}=(2 C \nu) / A$, where $\nu$ is the potential scan rate and $A$ is the electrode area. ${ }^{37}$ Measured $C$ values decreased with increasing [virus] $]_{\text {soln }}$ and ranged from $340 \mu \mathrm{F} / \mathrm{cm}^{2}$ for pure PEDOT to $260 \mu \mathrm{F} / \mathrm{cm}^{2}$ for films prepared from [virus $]_{\text {soln }}=15$ $\mathrm{nM}$ (Figure $3 \mathrm{~b}$ ). These $C$ values exceed that of the bare gold surface $\left(25-35 \mu \mathrm{F} / \mathrm{cm}^{2}\right)$, a fact that is consistent with the known porosity and electronic conductivity of PEDOT films. ${ }^{36}$ Measured values of $C$ were directly proportional to $Q_{\text {tot }}$ independent of [virus $]_{\text {soln }}$ (Figure $3 \mathrm{c}$ ). The fact that all of the capacitance data for virus-PEDOT films fall onto the same line implies that the incorporation of virus particles into the biocomposite does not alter the capacitance produced by the PEDOT component of the film, the quantity of which linearly correlates with $Q_{\text {tot }}$

To determine the effect of the incorporation of viruses on the vertical film conductivity, $\sigma_{\|}$(i.e., the conductivity of the biocomposite film measured parallel to its growth direction and perpendicular to the working electrode), virus-PEDOT films prepared from a range of [virus $]_{\text {soln }}$ concentrations were studied using c-AFM (Figure 4). Concurrent topography and current images, acquired using a constant imaging bias, were acquired for films of pure PEDOT and three films prepared from polymerization solutions with $[\text { virus }]_{\text {soln }}=3,9$, and $15 \mathrm{nM}$. Shown in Figure $4 \mathrm{a}$ are two pairs of representative c-AFM images for the pure PEDOT film (Figure 4a,b) and a film prepared using [virus $]_{\text {soln }}=9 \mathrm{nM}$ (Figure $4 \mathrm{c}, \mathrm{d}$ ). As was already indicated, the topography of pure PEDOT films was featureless with a rms roughness of $12 \mathrm{~nm}$. The film $\sigma_{\|}$was calculated from such c-AFM images by assuming a tip contact area of $100 \mathrm{~nm}^{2}$ as previously described. ${ }^{38}$ The $\sigma_{\|}$of pure PEDOT films was spatially invariant with a mean value of $270 \mu \mathrm{S} / \mathrm{cm}$. This value is approximately 4 orders of magnitude lower than $\sigma_{\perp}$ previously measured for PEDOT films in our group. ${ }^{39} \mathrm{~A}$ similar disparity between $\sigma_{\|}$and $\sigma_{\perp}$ with $\sigma_{\perp} / \sigma_{\|} \approx 1000$ has been reported for films of PEDOT/PSS (PSS = poly(4styrenesulfonic acid))..$^{40,41}$ For that material, this anisotropy has been attributed ${ }^{40}$ to the existence of a lamellar structure in which layers of pure PEDOT are separated by thinner PSS layers, but direct microscopic or diffraction evidence for this layered morphology has not been obtained so far. If M13 virus particles form analogous layers within virus-PEDOT biocomposite film, then electronic transport in the direction parallel to the growth direction would be impeded just as reported for PEDOT/PSS.
While the average value of $\sigma_{\|}$is reduced by the incorporation of virus particles (Figure 4e), c-AFM images for PEDOT films prepared from virus-containing solutions (Figure $4 \mathrm{c}, \mathrm{d}$ ) also show much greater variation in the electrical conductivity than is seen for pure PEDOT films. For virus-PEDOT films, protrusions are seen in the topography image (Figure 4c) that correlate with high current features in the current map of the surface (Figure 4d). As was already indicated above, these protrusions seem to be caused by entrained virus particles in the PEDOT film, but because M13 virus particles are not electronically conductive, we believe these virus particles are overcoated with a conductive PEDOT layer. This hypothesis is also consistent with the diameter of these fibers, which is enlarged by $20-80$ times compared to the $6 \mathrm{~nm}$ diameter of M13 (Figure 2). In previous work, Niu et al. ${ }^{21,23,24}$ have shown that biocomposite fibers containing M13 or TMV can be prepared by wrapping these viruses with conductive polymers to produce structures similar to those seen in Figure 2. This wrapping process occurs spontaneously during the homogeneous polymerization of the polymer in virus-containing aqueous solutions, ${ }^{21,23,24}$ so it is possible that this wrapping process also occurs for virus particles during heterogeneous polymerization at an electrode surface.

The data presented above show that properties of virusPEDOT films, including the topography of these films, the electrical conductivity, and the electrochemical capacitance, are all altered as a function of [virus $]_{\text {soln }}$. These data provide indirect evidence for the incorporation of virus particles into the PEDOT film during the electrodeposition process. Direct evidence for virus incorporation is provided by measuring the mass of the biocomposite film using the quartz crystal microbalance (QCM) (Figure 5). A plot of frequency versus time for the electrodeposition of a pure PEDOT film using 10 voltammetric scans (Figure 5a) shows stepwise decreases that correlate with the electrodeposition of PEDOT onto the QCM crystal. After every two deposition cycles, the QCM mass was allowed to stabilize so that an accurate frequency change could be recorded. A plot of frequency versus $Q_{\text {tot }}$ acquired in solutions of varying [virus] $]_{\text {soln }}$ (Figure $5 \mathrm{~b}$ ) shows two significant results: First, as the virus concentration increases, $Q_{\text {tot }}$ for the 10-cycle deposition decreases (Figure 5c, blue data). This result shows very clearly that the presence of virus in the plating solution impedes the polymerization of EDOT. Second, $\Delta f$ versus $Q_{\text {tot }}$ is quasi-linear for each solution, and the 
slope of these plots increases with increasing $[\text { virus }]_{\text {soln }}$. This means that the mass increase per unit deposition charge is augmented approximately in proportion to [virus $]_{\text {soln }}$ (Figure $5 c$, red trace). These data are consistent with the incorporation of virus into the virus-PEDOT biocomposite film in amounts that depend upon [virus $]_{\text {soln }}$. However, a meaningful measurement of the concentration of virus in the virus-PEDOT film, [virus $]_{\text {film }}$, requires drying of the film, as described next.

The mass changes measured in situ may not accurately represent the mass of virus particles mainly because the mass of additional water contributes to this total mass measurement. ${ }^{42}$ To remove the mass of the water, we also performed ex situ QCM measurements on PEDOT and virus-PEDOT biocomposite films after rinsing and oven drying. First, a baseline QCM measurement was made on a clean crystal in air. Next, either PEDOT or virus-PEDOT was electrodeposited onto this crystal; it was removed from the deposition solution, rinsed, and dried in a $175^{\circ} \mathrm{C}$ for $6 \mathrm{~h}$ to remove the hydrated water. After the crystal returned to room temperature in a desiccator, the mass of the crystal was measured a second time using the QCM to obtain the dehydrated mass of the film. The difference between the final and initial mass measurements yielded the mass of the dried film. We acquired these $\Delta f$ versus $Q_{\text {tot }}$ data for six pure PEDOT films (Figure 6a, black data points) that show

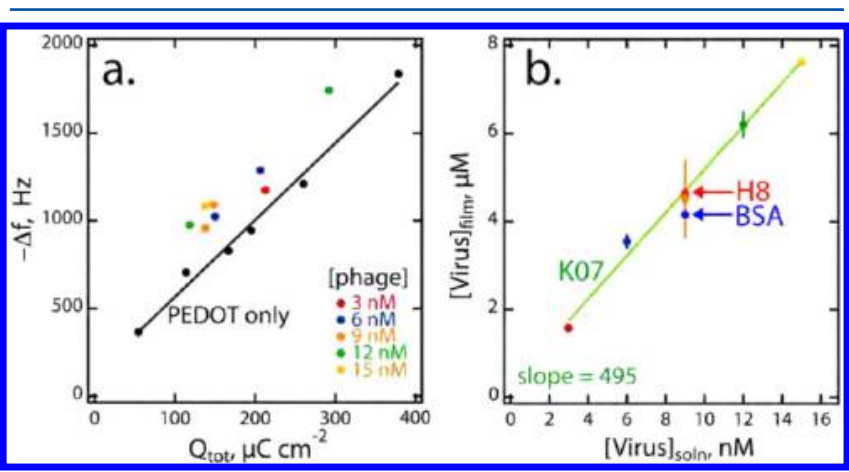

Figure 6. QCM data for dried PEDOT and virus-PEDOT films. (a) Change in frequency of dried virus-PEDOT films with various concentrations of virus incorporated versus deposition charge. A calibration was generated using PEDOT-only films as seen in black to compare mass versus charge data. The frequency-to-mass conversion factor for the QCM is $49.0 \pm 0.7 \mathrm{~Hz} \mathrm{~cm}^{2} \mu \mathrm{g}^{-1}$. (b) Calibration curve for surface coverage of viruses in films versus concentration of virus in solution. Viruses with peptides displayed on their surface, prostate specific membrane antigen (PSMA) binding peptides (red) and bovine serum albumin (BSA) binding peptides (blue), were also incorporated to show that the presence of a displayed nonnatural polypeptide on the virus surface has little influence on its propensity to be incorporated into the PEDOT film.

a linear mass increase as a function of $Q_{\text {tot }}$. Also measured were biocomposite films prepared using [virus $]_{\text {soln }}=3-15 \mathrm{nM}$ (colored data points) and $9 \mathrm{nM}$ solutions of two other viruses: $\mathrm{H} 8$, an M13 variant displaying a peptide that selectively binds prostate specific membrane antigen (PSMA), and BSA virus, an M13 variant displaying a peptide that selectively binds bovine serum albumin (BSA). For all of these virus-containing films, the mass is shifted higher from the linear PEDOT calibration (Figure 6a). This shift results from the incorporation of virus into the PEDOT film. From this shift, the mass of virus added into the virus-PEDOT film can be calculated. We then normalized this mass by the thickness of the virus-PEDOT film, measured for each dried film using AFM, to obtain the concentration of virus in the dried biocomposite film (Figure $6 \mathrm{~b})$. We find that the virus concentration within the PEDOT films increases linearly with its concentration in the solution. The slope of this plot, representing the ratio [virus $]_{\text {film: }}$ : $[\text { virus }]_{\text {soln }}=495$, demonstrates that virus is efficiently incorporated from solution into the growing PEDOT film. The surface coverage of incorporated virus, $\Gamma$, can also be calculated and ranges from $2.4 \mu \mathrm{g} \mathrm{cm}^{-2}$ for [virus $]_{\text {soln }}=3 \mathrm{nM}$ virus to $7.2 \mu \mathrm{g} \mathrm{cm}^{-2}$ for [virus] $]_{\text {soln }}=15 \mathrm{nM}$ virus (Table 1 ). We also find that the two engineered virus particles capable of binding BSA and PSMA both fall close to this linear calibration, suggesting that the displayed peptides present on the capsid of these viruses do not interfere with their incorporation into the PEDOT film.

Why is the incorporation of M13 into the virus-PEDOT film so efficient? The electropolymerization of EDOT occurs according to the reaction shown in Scheme 1 (top). For the

Scheme 1. Electropolymerization of PEDOT in Electrolytes Containing Perchlorate (Top) and M13

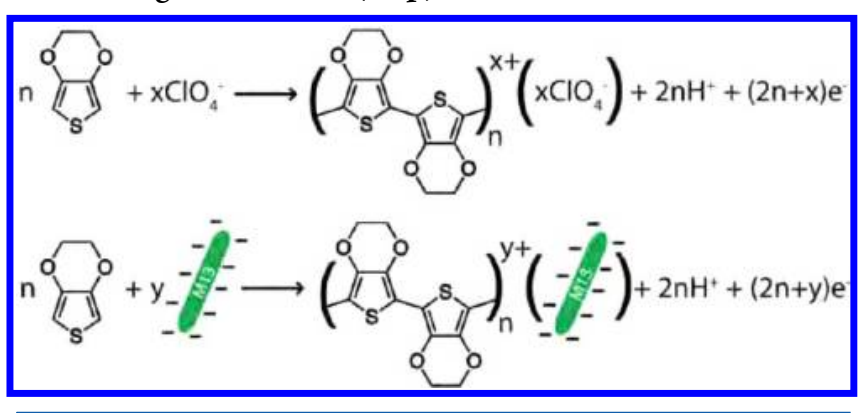

oxidized form of the PEDOT in perchlorate electrolyte, the value of $x$ in Scheme 1 is $0.30 .^{42}$ In our experiments, a small concentration of $\mathrm{ClO}_{4}^{-}(12.5 \mathrm{mM})$ is augmented by a $3-15 \mathrm{nM}$ concentration of M13. Our hypothesis is that the incorporation of M13 into PEDOT films is promoted by the fact that M13 has a large negative charge at $\mathrm{pH}=7.2$ : The principal coat peptide of the virus, P8, contains three amino acids (Glu2, Asp4, and Asp5) near the N-terminus on the outer surface of the virus capsid that are negatively charged at physiological $\mathrm{pH}^{43,44}$ Because the main portion of the M13 capsid is composed of 2700 copies of $\mathrm{P} 8,{ }^{43}$ the total negative charge on the virus surface is large, and a significant Coulombic driving force exists for the incorporation of M13 into the positively charge PEDOT film formed by electropolymerization (Scheme $1)$.

\section{CONCLUSIONS}

M13 bacteriophage ( $\mathrm{MW}=16.4 \mathrm{MDa})$ can be incorporated into films of the electrically conductive polymer film, PEDOT, during electrodeposition in a concentration-dependent manner. Virus incorporation into the growing PEDOT film is efficient and culminates in the formation of virus-PEDOT films containing $\sim 8 \mu \mathrm{M}$ concentrations of virus from $15 \mathrm{nM}$ solutions, a concentration factor of $\sim 495$. The loading of virus into the PEDOT film is linearly correlated with the concentration of virus in the EDOT polymerization solution. Increasing the virus loading interferes with PEDOT polymerization, reducing the polymerization rate, while simultaneously causing a reduction in the film of the electrical conductivity as evidenced both by capacitance measurements and by c-AFM measurements of biocomposite films. The reported results 
make it possible to optimize the biosensing performance of virus-PEDOT films with a more complete understanding of exactly how much virus is present in these films and how virus incorporation influences the electrical conductivity of these biocomposite films.

\section{AUTHOR INFORMATION}

\section{Corresponding Author}

*E-mail: gweiss@uci.edu (G.A.W.); rmpenner@uci.edu (R.M.P.).

\section{Notes}

The authors declare no competing financial interest.

\section{ACKNOWLEDGMENTS}

K.C.D. acknowledges financial support of this work from the National Science Foundation IGERT fellowship (DGE0549479). R.M.P. acknowledges financial support of this work from the National Science Foundation (CHE-0956524). G.A.W. acknowledges financial support of this work from the NAID (1 R43 AI074163) and the NCI (R01 CA133592-01) of the National Institutes of Health.

\section{REFERENCES}

(1) Cen, L.; Neoh, K.; Kang, E. Langmuir 2002, 18, 8633-8640.

(2) Widge, A. S.; Jefferies-El, M.; Cui, X.; Lagenaur, C. F.; Matsuoka, Y. Biosens. Bioelectron. 2007, 22, 1723-1732.

(3) Richardson-Burns, S. M.; Hendricks, J. L.; Foster, B.; Povlich, L. K.; Kim, D.-H.; Martin, D. C. Biomaterials 2007, 28, 1539-1552.

(4) You, J.; Yoshida, A.; Heo, J. S.; Kim, H.-S.; Kim, H. O.; Tamada, K.; Kim, E. Phvs. Chem. Chem. Phvs. 2011, 13, 17625-17632.

(5) Rivers, T. J.; Hudson, T. W.; Schmidt, C. E. Adv. Funct. Mater. 2002, 12, 33-37.

(6) Ravichandran, R.; Sundarrajan, S.; Venugopal, J.; Mukherjee, S.; Ramakrishna, S. J. R. Soc. Interface 2010, 7, S559-S579.

(7) Ahuja, T.; Mir, I. A.; Kumar, D.; Rajech. Biomaterials 2007, 28, 791-805.

(8) Cosnier, S. Electroanalysis 2005, 17, 1701-1715.

(9) Cosnier, S. Anal. Bioanal. Chem. 2003, 377, 507-520.

(10) Teles, F.; Fonseca, L. Mater. Sci. Eno. C 2008, 28, 1530-1543.

(11) Gerard, M.; Chaubey, A.; Malhotra, B. Biosens. Bioelectron. 2002, $17,345-359$.

(12) Ionescu, R. E.; Cosnier, S.; Herrmann, S.; Marks, R. S. Anal. Chem. 2007, 79, 8662-8668.

(13) Xie, H.; Luo, S.-C.; Yu, H.-H. Small 2009, 5, 2611-2617.

(14) Bruckman, M. A.; Liu, J.; Koley, G.; Li, Y.; Benicewicz, B.; Niu, Z.; Wang, Q. L. Mater. Chem. 2010, 20, 5715-5719.

(15) Cosnier, S.; Holzinger, M. Chem. Soc. Rev. 2011, 40, 21462156.

(16) Asplund, M.; von Holst, H.; Inganas, O. Colloids Surf. B 2008, 3, 83-93.

(17) Guimard, N. K.; Gomez, N.; Schmidt, C. E. Prog. Polvm. Sci. 2007, 32, 876-921.

(18) Luo, S.-C.; Ali, E. M.; Tansil, N. C.; Yu, H.-H.; Gao, S.; Kantchev, E. A. B.; Ying, J. Y. Lanomuir 2008, 24, 8071-8077.

(19) Abidian, M. R.; Martin, D. C. Biomaterials 2008, 29, 12731283.

(20) Xiao, Y.; Li, C. M.; Wang, S.; Shi, J.; Ooi, C. P. I. Biomed. Mater. Res. Part A 2010, 92, 766-772.

(21) Niu, Z.; Bruckman, M. A.; Harp, B.; Mello, C. M.; Wang, $\underline{\text {. }}$ Nano Res. 2008, 1, 235-241.

(22) Li, K.; Chen, Y.; Li, S.; Nguyen, H.; Niu, Z.; You, S.; Mello, C.; Lu, X.; Wang, Q. Bioconiugate Chem. 2010, 21, 1369-1377.

(23) Niu, Z.; Bruckman, M. A.; Li, S.; Lee, L. A.; Lee, B.; Pingali, S. V.; Thiyagarajan, P.; Wang, Q. Langmuir 2007, 23, 6719-6724.

(24) Niu, Z.; Liu, J.; Lee, L. A.; Bruckman, M. A.; Zhao, D.; Koley, G.; Wang, Q. Nano Lett. 2007, 7, 3729-3733.
(25) Arter, J. A.; Diaz, J. E.; Donavan, K. C.; Penner, R. M.; Weiss, G. A. Anal. Chem. 2012, 84, 2776-2783.

(26) Donavan, K. C.; Arter, J. A.; Pilolli, R.; Cioffi, N.; Weiss, G. A.; Penner, R. M. Anal. Chem. 2011, 83, 2420-2424.

(27) Arter, J. A.; Taggart, D. K.; McIntire, T. M.; Penner, R. M.; Weiss, G. A. Nano Lett. 2010, 10, 4858-4862.

(28) Berkowitz, S.; Day, L. Biochemistry 1980, 19, 2696-2702.

(29) Che, A.-F.; Huang, X.-J.; Xu, Z.-K. Macromol. Biosci. 2010, 10, 955-962.

(30) Marx, K. A. Biomacromolecules 2003, 4, 1099-1120.

(31) Cheng, C. I.; Chang, Y.-P.; Chu, Y.-H. Chem. Soc. Rev. 2012, 41, 1947-1971.

(32) Becker, B.; Cooper, M. I. Mol. Recognit. 2011, 24, 754-787.

(33) Buttry, D. A.; Ward, M. D. Chem. Rev. 1992, 92, 1355-1379.

(34) Yang, L.-M. C.; Diaz, J. E.; McIntire, T. M.; Weiss, G. A.; Penner, R. M. Anal. Chem. 2008, 80, 933-943.

(35) Yang, L.-M. C.; Diaz, J. E.; McIntire, T. M.; Weiss, G. A.; Penner, R. M. Anal. Chem. 2008, 80, 5695-5705.

(36) Sotzing, G.; Reynolds, J.; Steel, P. Adv. Mater. 1997, 9, 795.

(37) Bard, A. J.; Faulkner, L. R. Electrochemical Methods: Fundamentals and Applications; Wiley: New York, 2000.

(38) Pingree, L. S. C.; MacLeod, B. A.; Ginger, D. S. I. Phvs. Chem. C 2008, 112, 7922-7927.

(39) Taggart, D. K.; Yang, Y.; Kung, S.-C.; McIntire, T. M.; Penner, R. M. Nano Lett. 2011, 11, 125-131.

(40) Nardes, A. M.; Kemerink, M.; Janssen, R. A. J.; Bastiaansen, J. A. M.; Kiggen, N. M. M.; Langeveld, B. M. W.; van Breemen, A. J. J. M.; de Kok, M. M. Adv. Mater. 2007, 19, 1196.

(41) Nardes, A. M.; Kemerink, M.; Janssen, R. A. I. Phys. Rev. B 2007, 76,085208 .

(42) Efimov, I.; Winkels, S.; Schultze, J. I. Electroanal. Chem. 2001, 499, 169-175.

(43) Marvin, D.; Hale, R.; Nave, C.; Citterich, M. I. Mol. Biol. 1994, 235, 260-286.

(44) Marvin, D. Curr. Opin. Struct. Biol. 1998, 8, 150-158.

(45) Eguilaz, M.; Agui, L.; Yanez-Sedeno, P.; Pingarron, I. I. Electroanal. Chem. 2010, 644, 30-35.

(46) Chen, Z.-W.; Balamurugan, A.; Chen, S.-M. Bioelectrochemistry 2009, 75, 13-18.

(47) Luo, S.-C.; Xie, H.; Chen, N.; Yu, H.-H. ACS Appl. Mater. Interfaces 2009, 1, 1414-1419. 